\title{
Method for a Drainage Roadway Location Determi- nation for an Overlying Methane Drainage System
}

\author{
Marek Borowski $^{1, *)}$, Marek Cała ${ }^{2)}$
}

\footnotetext{
1) Department of Environmental Engineering, AGH University of Science and Technology, 30 Mickiewicza str., Krakow, 30-059, Poland; Email: borowski@agh.edu.pl

2) Department Department of Geomechanics, Civil Engineering and Geotechnics, AGH University of Science and Technology,

30 Mickiewicza str., Krakow, 30-059, Poland; email: cala@agh.edu.pl
}

http://doi.org/10.29227/IM-2020-02-25

Submission date: 06-03-2020 | Review date: 22-09-2020

\section{Abstract}

The paper analyses possibilities to carry out methane drainage of a longwall in seam 510. A possibility to fight against the methane hazard was determined based on results of forecasting for methane emission to mine workings. A system of methane drainage was suggested for the adopted method of longwall face ventilation. The location of drainage roadway was determined for the selected methane drainage system. The paper includes a geomechanical analysis for a numerical model, which was aimed at determination of the optimum location of the drainage roadway in a seam overlying the longwall panel.

Keywords: methane hazard, methane drainage, overlying drainage, drainage roadway, geomechanical analysis, numerical model

\section{Introduction}

The performance of underground mining is always related to disturbance to the hitherto equilibrium condition, existing in the rock mass surrounding the deposit. The condition is the outcome of many factors such as stratified structure, depth of mining, tectonic stresses, or previously carried out mining. In addition, natural hazards impose on the mining, and the methane hazard has a special impact because nearly $80 \%$ of mining is carried out under these hazard conditions [1].

In a coal seam methane exists in the form of molecules absorbed on coal grains and in a free form, filling the pores. The flow of methane through strata and seams is a very complex process. It results both from the physicochemical interaction of the framework with the flowing gas and also from a fracture-pore structure of rock mass $[2,3]$.

A number of solutions are applied, such as intensive ventilation or me-thane drainage, aimed at reduction of the hazard to achieve the planned output under methane hazard conditions. One of the methods used in conditions of a high methane hazard consists of the application of methane drainage system with an overlying drainage roadway. The determination of roadway location to achieve effective methane capture is a major challenge. Therefore to determine the optimum drainage roadway location in the desorption zone, a geomechanical analysis was performed based on the developed numerical model of a deposit part [4].

\section{Description of mining conditions and of methane hazard}

Within the planned longwall seam 510 features a high variability of deposition and a significant diversification of thickness. On the eastern side the longwall neighbours the zone of seam thinning $(2.0 \mathrm{~m})$ and narrowing $(0.0-1.0 \mathrm{~m})$. The seam thickness increases westwards. As it results from the geological cross-section seam 510 is approx. $2.8 \mathrm{~m}$ thick along the air roadway parallel to the line of longwall length. At the panel length of $320 \mathrm{~m}$ the seam thickness is approx. $3.5 \mathrm{~m}$.
This is an average thickness, which the seam should feature within the planned longwall. However, the thickness can be smaller and greater up to $4.0 \mathrm{~m}$. The longwall panel will be mined along the strike with roof caving. The seam inclination angle is $8^{\circ}$.

Based on the survey of methane content in coal in the planned mining panel, the methane content was found to be from 5 to $10,5 \mathrm{~m}^{3} / \mathrm{Mg}$ csw. The highest methane content should be expected in the initial longwall run, but with the longwall panel length, the methane content will be decreasing till the finish.

Results of the forecast calculated depending on the daily output and on the longwall panel length were used to analyse the methane emission to mine workings in the longwall face. The calculations were performed by means of a dynamic method for longwall absolute methane content forecast-ing developed at the Central Mining Institute (GIG). The data related to geological conditions were adopted based on the geological documentation of the hard coal deposit, and in particular on geological rock profiles. The highest methane emission occurs in the initial longwall run, which at the output of $3000 \mathrm{Mg} / \mathrm{d}$ reaches $44 \mathrm{~m}^{3} / \mathrm{min}$, while for the output of $4500 \mathrm{Mg} / \mathrm{d}$ the amount of $54 \mathrm{~m}^{3} / \mathrm{min}$ should be expected. The sources of methane emission to the longwall working will comprise:

- roof layers $45 \%$,

- mined seam $40 \%$,

- floor layers $15 \%$.

Because of high methane hazard in mine workings, such amounts of air should be ensured, which would secure maintaining the methane concentrations in the air on a permissible level. The comparison of forecast and criteria methane content shows that it is not possible to carry out mining without the methane drainage application.

Under conditions of the analysed longwall face, it is not possible to apply the $\mathrm{U}$ ventilation system from boundaries 


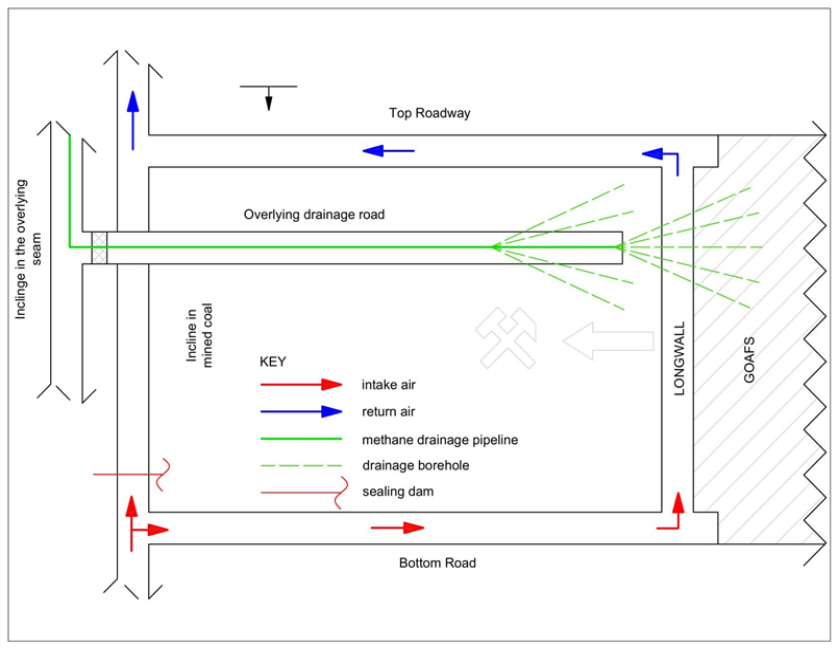

Fig. 1. Diagram of ventilation and methane drainage with a drainage roadway Rys. 1. Schemat wentylacji i odmetanowania $z$ chodnikiem odwadniającym

together with methane drainage due to the forecast methane emission, which results from relatively low methane drainage effectiveness of such solution. Also, methane drainage systems from a parallel air roadway, or from the roadway fenced with so-called fringe drift, do not ensure the required effectiveness for the planned output. Calculations show that for the planned longwall, only the application of methane drainage system from an overlying roadway will ensure methane capture at the amount demanded to achieve the planned output. Fig. 1 presents the ventilation system with the overlying methane drainage system.

An overlying roadway is driven at some distance above the mined longwall face, from which drainage boreholes are drilled towards goaves of the mined longwall. Fig. 1 presents an example of drainage boreholes situation, drilled from an overlying drainage roadway.

\section{Determination of desorption zone and selection of meth- ane drainage system}

Basic conditions deciding about effective methane drainage include:

- the necessity to situate drainage boreholes in the decompression zone, i.e. in methane emission places,

- maintaining the drainage boreholes connected to the decompression source behind the longwall front:

- the lowest methane inflow to boreholes occurs at a distance of approx. $10 \mathrm{~m}$ ahead of the longwall front,

- the highest methane inflow occurs approx. $30 \mathrm{~m}$ behind the longwall front,

- the methane inflow stops approx. $250 \mathrm{~m}$ behind the longwall front.

In the case of methane drainage from adjacent seams, it is necessary to determine the desorption zone caused by the longwall mining. Drainage boreholes should be situated in such a way as to be in the decompressed zone, but not cut the direct caving zone.

Under Polish geological conditions, good results are provided by determination of the desorption zone, in which drainage boreholes are situated. Fig. 2 presents the desorption zone in the direction of the roof and floor layers. For the ana- lysed longwall the range of desorption zone in roof layers was $157.5 \mathrm{~m}$, while the range of desorption zone in-floor layers was $52.7 \mathrm{~m}$.

Boreholes are usually drilled parallel to the longwall face, and then the borehole inclination angle corresponds roughly to the angle of desorption range. An appropriate correction should be considered in the case of drilling boreholes sloping against the longwall face. The borehole length results from geological conditions, and primarily from the location of coal seams which are the methane carriers. If technically feasible, it is necessary to strive that boreholes cut all seams situated in the decompressed zone (desorption zone).

A methane drainage system with a drainage roadway in an overlying seam was proposed for the analysed case. The principle of the system consists in driving above the mined seam, in an accompanying non-commercial seam (not intended for mining), of a special roadway, referred to as the drainage (methane) roadway. This roadway should be situated in the zone of rock mass covered by the desorption range.

The distance between the mined seam and the drainage roadway should not be smaller than 5-times the mining thickness, and at the same time not smaller than $12 \mathrm{~m}$. The horizontal shift of the drainage roadway from the desorption zone edge on the longwall air roadway side (value selected empirically) should be:

$s=0.15 / 0.5 \cdot \mathrm{L}=0.3 \cdot \mathrm{L}$

where: $\mathrm{L}$ - longwall face length, $\mathrm{m}$.

From the drainage roadway, towards the hanging and lying wall, bundles of drainage boreholes can be drilled at distances of about $50 \mathrm{~m}$, featuring typical diameters and the following directions:

* hanging wall boreholes:

- length - 30-40 m

- deflection - 30-45

- inclination $-20-30^{\circ}$

* lying wall boreholes:

- length - 40-60 m

- deflection $-20-45^{\circ}$

- inclination $-30-60^{\circ}$ 


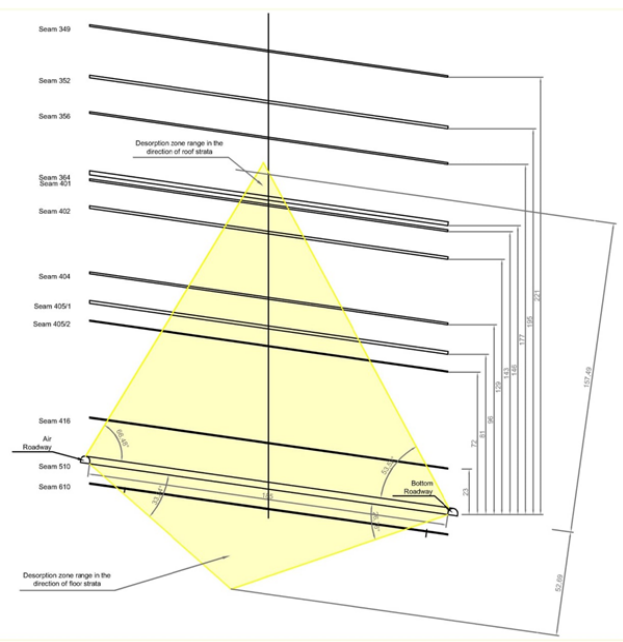

Fig. 2. Drainage boreholes location in the desorption zone for the longwall from the top road Rys. 2. Położenie otworów odwadniających w strefie desorpcji dla ściany od strony wyżej leżącego chodnika.

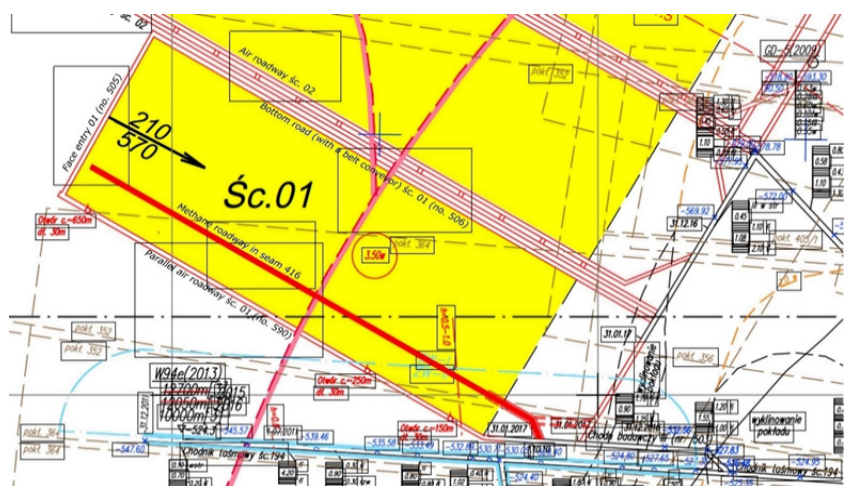

Fig. 3. Drainage roadway location behind the longwall panel

Rys. 3. Położenie chodnika odwadniającego za płytą ścianową

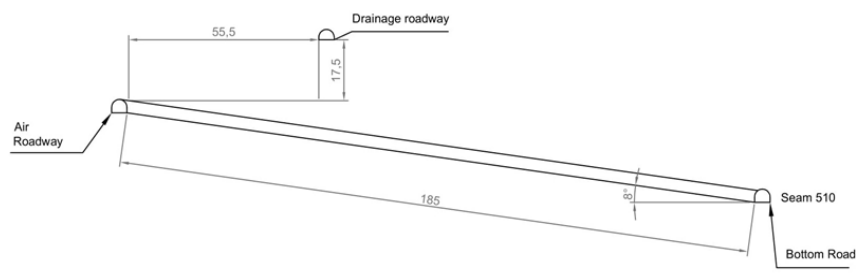

Fig. 4. Drainage roadway location in the cross-section

Rys. 4. Położenie chodnika odwadniajcego w przekroju poprzecznym

These boreholes are drilled to accompanying seams, improving the rock mass drainage, but it is not advisable to make them in that seam, in which the drainage roadway is situated. These boreholes are made without the application of casing.

After the performance of the full scope of drilling works, the roadway support may be withdrawn. The roadway entry is insulated with a tight insulation plug, through which methane pipelines and control (measuring) pipelines are conducted. Methane is captured almost only from behind the insulation plug, excluding the initial period of longwall run, during which, due to missing connections in the caving, methane cannot be captured by means of overlying drainage. In that period methane drainage can be carried out by drainage boreholes, made from the top road. After the period in which the longwall will underwork the drainage roadway at a distance of approx. $50 \mathrm{~m}$, the borehole methane drainage usually becomes unnecessary. There is no need to make boreholes along the entire drainage roadway length.

Based on the hitherto experience it is possible to state that the overlying drainage method is especially useful in such cases, where the majority of methane emission originates from the mined seam and from underworked seams (situated in the roof), as it is the case of seam 510 . The number and total thickness of underworked seams, affected by methane drainage, is extremely important - the higher that thickness, the better is the obtained result of methane drainage.

A proper situation of methane roadway in the longwall methane drainage space is significant at the application of overlying drainage. This roadway should be situated in the methane drainage space in the high caving zone, where high 


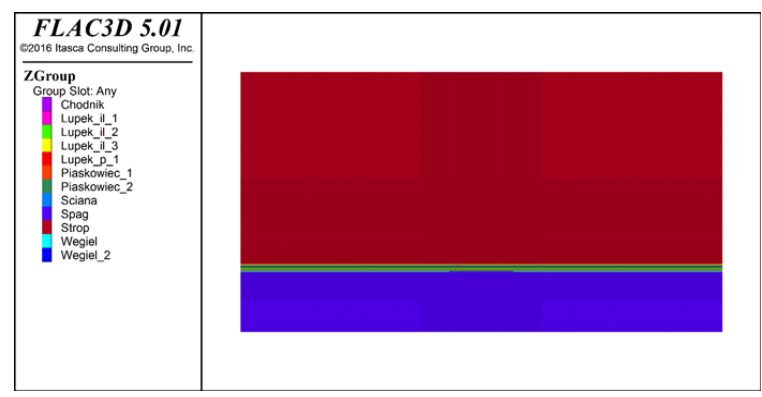

Fig. 5. Model geometry adopted in the analysis

Rys. 5. Geometria modelu przyjęta do analizy

Tab. 1. Specification of strength parameters adopted in calculations

Tab. 1. Parametry wytrzymałości przyjęte w obliczeniach

\begin{tabular}{|l|c|c|c|}
\hline \multicolumn{1}{|c|}{ Stratum } & $\begin{array}{c}\text { Angle of internal friction } \varphi \\
{\left[{ }^{\circ}\right]}\end{array}$ & Cohesion, c [MPa] & $\begin{array}{c}\text { Tensile strength, } \\
\mathrm{R}_{\mathrm{r}}[\mathrm{MPa}]\end{array}$ \\
\hline Floor & 42.35 & 2.204 & 1.03 \\
\hline Coal & 30.0 & 1.0 & 1.0 \\
\hline Clay_shale_1 & 27.35 & 1.179 & 1.02 \\
\hline Silt_shale 2 & 33.5 & 1.708 & 1.69 \\
\hline Clay_shale_2 & 31.97 & 1.553 & 1.171 \\
\hline Sandstone_1 & 42.74 & 4.492 & 4.492 \\
\hline Clay_shale_2 & 31.97 & 1.553 & 4.171 \\
\hline Sandstone_2 & 42.35 & 4.408 & 1.08 \\
\hline Coal_2 & 30.0 & 1.0 & 1.122 \\
\hline Clay_shale 3 & 31.37 & 1.498 & 4.408 \\
\hline Roof & 42.35 & 4.408 & \\
\hline
\end{tabular}

methane concentrations exist, and at the same time, the rock permeability is high enough to ensure a free flow of gas.

\section{Determination of drainage roadway location}

The drainage roadway should be driven above the longwall mining panel. Drainage boreholes should be drilled from the drainage roadway to increase the effectiveness of methane drainage. It was anticipated that the roadway would be situated in the high caving zone and above the direct caving zone. The roadway was to be driven in the overlying seam 416 , which is $1.2-1.6 \mathrm{~m}$ thick. This seam exists at a distance of over $20 \mathrm{~m}$ above the mined seam $[3,5]$.

Calculations based on Formula (1) show that the horizontal distance of the drainage roadway from the longwall air roadway should be $55 \mathrm{~m}$. The drainage roadway in seam 416 would be connected with the air roadway by a drift made beyond the range of mining influence of the mined longwall. The drainage roadway should be driven to a distance of $15 \mathrm{~m}$ (in vertical projection) from the raised face (being the longwall face). The drainage roadway will be in total $600 \mathrm{~m}$ long.

The drainage roadway location above the longwall mining panel is presented in a part of the seam map in Fig. 3. Instead, Fig. 4 presents the drainage roadway location in the cross-section, together with the distance from the air roadway.

\section{Assumptions for numerical analysis of drainage roadway location}

A numerical analysis was performed to determine a convenient location of the drainage roadway behind the longwall panel. A numerical model in the form of a flat target of dimensions 1600x850 $\mathrm{m}$ was developed for this purpose, based on geological cross-sections and on borehole logs. This model was digitised with elements of dimensions from approx. 2x2 $\mathrm{m}$ in the central part of the model, to approx. 10x2 $\mathrm{m}$ at the edges. A longwall, $185 \mathrm{~m}$ long and $3.5 \mathrm{~m}$ thick, was situated in the model. Above the longwall, in seam 416, a roadway was situated with dimensions corresponding to the $\mathrm{EP} 9 / \mathrm{V} 32 / 4 / \mathrm{A}$ support. Fig. 5 presents the model geometry [6].

Calculations were performed for three variants of the roadway situation:

- Variant W1 - the roadway axis was shifted by $22.5 \mathrm{~m}$ against the longwall air roadway,

- $\quad$ Variant W2 - the roadway axis was shifted by $37.5 \mathrm{~m}$ against the longwall air roadway,

- Variant W3 - the roadway axis was shifted by $55.5 \mathrm{~m}$ against the longwall air roadway,

Because of results extensiveness, only results for variant W2 are presented further on.

Parameters of geological beds in the longwall roof were adopted based on results of examinations for cores of boreholes drilled in the air roadway. Because of the occurrence of thin beds, some generalisation was adopted in calculations. Table 1 presents strength parameters of consecutive beds - counting from the bottom, adopted in calculations. These parameters were obtained in the RocLab software, taking the data from strength tests and assuming an average depth of layers equal to $600 \mathrm{~m}$. The strata of sandstone are an exception, for which due to the rocks nature and hitherto experience, higher cohesion values were adopted. For the floor and roof strata, parameters were adopted as for the Sandstone_1 stratum. The average weight of beds of $2500 \mathrm{~kg} / \mathrm{m} 3$, Young's modulus of $12 \mathrm{GPa}$, and the Poisson ratio of 0.3 were taken in calculations $[7,8]$.

Calculations were performed in the FLAC3D software using the Coulomb-Mohr constitutive model. Shift boundary 


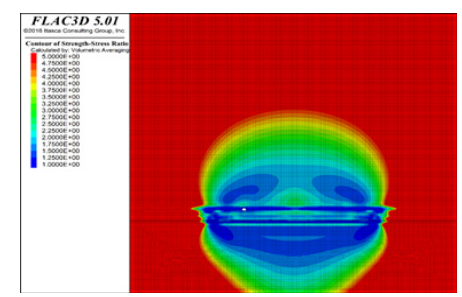

Fig. 6. Map of strength-stress ratio in the surroundings of longwall 01, seam 510 - variant W2 Rys. 6. Mapa relacji wytrzymałości do naprężeń w otoczeniu ściany 01, pokład 510 - wariant W2

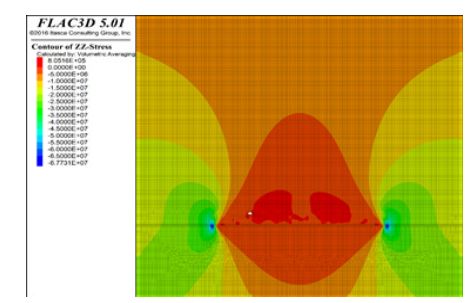

Fig. 7. Map of vertical stresses in the surroundings of longwall 01, seam 510 - variant W2 Rys. 7. Mapa naprężeń pionowych w otoczeniu ściany 01, pokład 510 - wariant W2

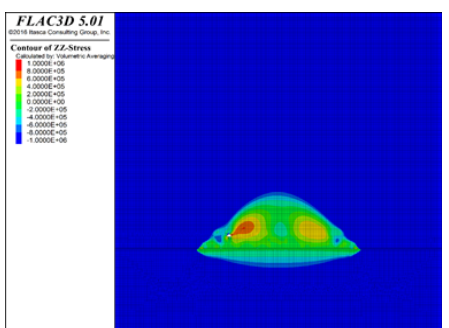

Fig. 8. Map of vertical stresses in the surroundings of longwall 01 , seam 510 , rescaled for values from a range of $1 \mathrm{MPa}$ to $-1 \mathrm{MPa}$ - variant W2 Rys. 8. Mapa naprężeń pionowych w otoczeniu ściany 01 , pokład 510 przeskalowana dla wartości w granicach od $1 \mathrm{MPa}$ do -1 MPa - wariant W2

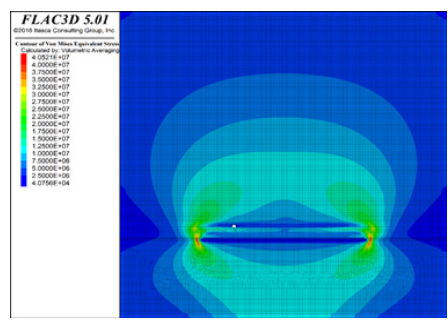

Fig. 9. Map of Von Mises stresses in the surroundings of longwall 01, seam 510 - variant W2 Rys. 9. Mapa naprężeń Von Misesa w otoczeniu ściany 01, pokład 510 - wariant W2

conditions were assumed, in the form of a blocked shift in directions perpendicular to side and bottom edges. Hydrostatic stress state $(\sigma \mathrm{xx}=\sigma \mathrm{yy}=\sigma \mathrm{zz})$ was assumed $[9,10]$.

\section{Results of Numerical Analysis}

Figures 6 to 8 present results for variant W2, i.e. for the situation, where the roadway axis is situated at a distance of $37.5 \mathrm{~m}$ from the air roadway axis of the analysed longwall. Fig. 6 presents the map of strength-stress ratio in the surroundings of the analysed longwall. It shows that the analysed roadway is situated in the zone of significant strength-stress ratios, which comprises the seam roof and reaches approx. 100 to $200 \mathrm{~m}$ above the seam. Then Fig. 7 presents the map of vertical stresses $(\sigma z z)$, while Fig. 8 the same map rescaled for values from a range of $1 \mathrm{MPa}$ to $-1 \mathrm{MPa}$. These maps show that the situation of roadway axis at a distance of around $37.5 \mathrm{~m}$ from the longwall edge will cause that it will be situated at the edge of vertical tensile stresses, that is in the place, where the highest rock damage zones are expected. However, it should be emphasised, that in this W2 variant the area of vertical tensile stresses close to the roadway is much larger, which causes greater fracturing of the rock medium in the roadway surroundings and better infiltration of gases towards the roadway. Fig. 9 presents the map of Von Mises stresses, which shows that the highest values exist in walls and just above the walls of the longwall.

\section{Conclusion}

The design of the analysed longwall predicts the mining along the strike with roof caving, at the assumed output of around $3900 \mathrm{Mg} / \mathrm{d}$. Preliminary studies have shown that a high methane hazard should be expected. In the planned area of mining, the methane content in the coal seam was found to be from 6 to $10.5 \mathrm{~m}^{3} / \mathrm{Mgcsw}$. The forecast methane emission 
to the longwall face reaches $50 \mathrm{~m} 3 / \mathrm{min}$. The sources of methane emission to the longwall face will comprise:

$$
\begin{aligned}
& \text { - roof layers } 45 \% \text {, } \\
& \text { - mined seam } 40 \% \text {, } \\
& \text { - floor layers } 15 \% .
\end{aligned}
$$

The comparison of forecast absolute methane content and criteria methane content shows that effective methane drainage can be ensured by the application of a drainage roadway in an overlying bed [11]. The overlying drainage method is especially useful in such cases, where the majority of methane emission originates from the mined seam and from underworked seams (situated in the roof). The number and total thickness of underworked seams, affected by methane drainage, is extremely important - the higher that thickness, the better is the obtained result of methane drainage, which applies to seam 510. Based on the calculations, for the determined desorption zone, the distance between the axis of drainage roadway in an overlying bed and the axis of longwall air roadway was determined. In the horizontal projection, this distance should be $55.5 \mathrm{~m}$.

A geomechanical analysis was performed around the analysed longwall to check, whether the drainage roadway is situated in the area of greatest decompression so that it could fulfil the function of methane capture in the determined desorption zone as effectively as possible. Three locations of the air roadway axis were considered, at a distance of 22.5M (variant W1), $37.5 \mathrm{~m}$ (variant W2), and $55.5 \mathrm{~m}$

(variant W3). The performed numerical analysis shows that the adopted location of the drainage roadway in variant W2 is most favourable from the geomechanics point of view. This results from the zone of larger tensile stresses on the right-hand side of the roadway, which will cause easier infiltration of gases towards the roadway. Such location should ensure convenient conditions for the methane flow to the drainage roadway, and at the same time, it would restrict unfavourable conditions existing around the roadway and related convergence. Zones of maximum Von Mises stress, wherefrom the geomechanical point of view the roadway location would be least favourable, are situated at a distance of around $40 \mathrm{~m}$ from the roadway axis.

It should also be added that the existence of strong sandstone layers, situated beneath the planned roadway, complicates the stress state in its surroundings. In the case of regular breaking of sandstone plates, favourable conditions should exist in the roadway surroundings, both in terms of methane and geomechanics, hence its functionality should be achieved.

Variant W3 (a distance of $55.5 \mathrm{~m}$ from the air roadway axis) is not recommended due to the occurrence of significant tensile stress zones on both sides of the roadway and likely related problems with maintaining its stability. 


\section{Literature - References}

1. Cheng J., Song W., Jing Y., Zhang X., Korzec M., Borowski M., Wang Y. (2020): Research on mine seal stability under explosion load and ground pressure in underground coal mines. Archives of Mining Sciences. vol. 65 no. 1, pp. 71-87. journals.pan.pl/Content/115960/PDF/Archiwum-65-1-06-Cheng.pdf?handler=pdf

2. Borowski M., Kuczera Z., (2018): Comparison of methane control methods in Polish and Vietnamese coal mines. E3S Web of Conferences; ISSN 2267-1242. vol. 35 art. no. 01004, pp. 1-8. www.e3s-conferences.org/articles/e3sconf/pdf/2018/10/e3sconf_polviet2018_01004.pdf [2018-04-05]. POL-VIET 2017 : scientific-research cooperation between Vietnam and Poland : Krakow, Poland, November 20-22, 2017

3. Borowski M., Łuczak R., Życzkowski P. (2019): Increase of methane intake through methane intake system with drainage excavation during longwall mining operations on a selected example. Conference - 10. Szkoła Aerologii Górniczej. Kraków. Wydawnictwo Instytutu Mechaniki Górotworu PAN, 2019. Archives of Mining Sciences; Monography; no 19, pp. 81-92.

4. Marinos P. and Hoek E. (2000). GSI - A geologically friendly tool for rock mass strength estimation. Proc. GeoEng2000 Conf., Melbourne.

5. Zhang X, Cheng J., Shi C., Xu X., Borowski M., Wang Y. (2020) :Numerical simulation studies on effects of explosion impact load on underground mine seal. Mining, Metallurgy \& Exploration ; vol. 37 issue. 2, pp. 665-680. link-1springer-1com-1nyztljh200a4.wbg2.bg.agh.edu.pl/ content/pdf/10.1007\%2Fs42461-019-00143-2.pdf.

6. Ulusay R., Hudson J.A. (Ed.), (2007): The complete ISRM suggested methods for rock characterizations, testing and monitoring: 1974-2006, Amsterdam, Turkey.

7. Hoek E. (2007). Practical Rock Engineering. Chapter 11, pp. 50.

8. Hoek E., Carranza-Torres C.T., and Corkum B. (2002), Hoek-Brown failure criterion - 2002 edition. Proc. North American Rock Mechanics Society meeting in Toronto in July 2002.

9. FLAC3D v. 5.0. (2013). User’s guide. Itasca Consulting Group. Minneapolis. USA.

10. FLAC3D v. 5.0. (2013). Theory and Background. Itasca Consulting Group. Minneapolis. USA.

11. Borowski M., Życzkowski P., Łuczak R., Karch M., Cheng J. (2020): Tests to ensure the minimum methane concentration for gas engines to limit atmospheric emissions. Energies. vol. 13 issue. 1 art. no. 44, pp. 1-15. www.mdpi. com/1996-1073/13/1/44/pdf

Wyznaczenia położenia chodnika drenażowego dla górnego systemu odprowadzania metanu $W$ artykule przedstawiono analizę możliwości prowadzenia odmetanowania ściany w pokładzie 510. Na podstawie wyników prognozy wydzielania metanu do wyrobisk górniczych określono możliwości zwalczania zagrożenia metanowego. Zaproponowano system odmetanowania $z$ chodnikiem drenażowym ponad eksploatowanym pokładem dla przyjętego sposobu przewietrzania wyrobiska ścianowego. Dla wybranego systemu odmetanowania wyznaczono lokalizację chodnika drenażowego. W artykule zamieszczono analize geomechaniczna dla modelu numerycznego, której celem było określenie optymalnej lokalizacji chodnika drenażowego pokładzie wyżej leżacym nad polem eksploatacyjnym.

Słowa kluczowe: zagrożenie metanowe, odmetanowanie, górne odwodnienie, chodnik drenażowy, analiza geomechaniczna, model numeryczy 